\title{
Chemical Speciation of some Heavy Metals in Sand Filter Media [SFM] Waste Dumpsite in Yenagoa, Nigeria
}

\author{
1*IKOKO, IL; ${ }^{2}$ OSU, CI; ${ }^{2}$ HORSFALL, M \\ *l Bayelsa State Ministry of Water Resources, Isaac Boro Expressway, Okaka, Yenagoa, Bayelsa State, Nigeria \\ ${ }^{2}$ Department of Pure \& Industrial Chemistry, University of Port Harcourt, Choba, Port Harcourt, Nigeria \\ *Corresponding Author Email: ifiemiikoko@gmail.com; Tel: +2348036713260, +234 7058628765
}

\begin{abstract}
The chemical speciation of five heavy metals [HMs] in spent sand-filter-media [SFM] waste dumpsite was investigated with a view to ascertain their distribution and chemical availability of the heavy metals in the dumpsite. Samples were collected at the surface, $100 \mathrm{~cm}$ depth of the dumpsite and $100 \mathrm{~m}$ away from the dumpsite and analysed using FAAS for total concentration of $\mathrm{Cr}, \mathrm{Fe}, \mathrm{Mn}$. $\mathrm{Ni}$ and $\mathrm{Pb}$. Speciation analysis was carried out using modified Tessier's sequential extraction method. The percentage concentrations showed that $\mathrm{Pb}$ occurred more at the exchangeable fraction with $90.6 \%$ at the top, $91.34 \%$ at $100 \mathrm{~cm}$ depth. This signifies that $\mathrm{Pb}$ is biochemically available for in-take by living organisms. Fe had the highest concentration by mass $12 \mathrm{mg} / \mathrm{g}$ but its occurrence of between 22$28 \%$ is in the residual/inert fraction. $\mathrm{Ni}$ had $40 \%$ in the exchangeable and carbonate fractions at the surface and at $100 \mathrm{~cm}$ depth. Cr had highest exchangeable fraction of $46.29 \%$ and $45.59 \%$ at the surface and $100 \mathrm{~cm}$ depth of the SFM. Mn had $37.30 \%$ and $42.26 \%$ at the surface and at $100 \mathrm{~cm}$ depth of the SFM. Although Fe had highest concentration by mass, it is least biochemically available occurring more at the residual/inert fraction while the other four metals $[\mathrm{Pb}$, $\mathrm{Ni}, \mathrm{Cr}, \mathrm{Mn}]$ are all biochemically available for intake by organisms and may enhance biochemical accumulation overtime and finally become harmful to living organisms around that dumpsite.
\end{abstract}

DOI: $\underline{\text { https://dx.doi.org/10.4314/jasem.v24i4.2 }}$

Copyright: Copyright (C) 2020 Ikoko et al. This is an open access article distributed under the Creative Commons Attribution License (CCL), which permits unrestricted use, distribution, and reproduction in any medium, provided the original work is properly cited.

Dates: Received: 16 February 2020; Revised: 24 March 2020; Accepted: 30 March 2020

Keywords: Speciation, Heavy metals, Sand Filter Media, Waste Dumpsite

Among the underground water contaminants, heavy metals are known to be of most concern to environmentalists because their compounds [ligands] are indeed still in reaction and are capable of many more reactions while the central metals themselves are relatively inert and can accumulate from small quantities to quite larger quantities (Dube et al. 2001). Further environmental concern of heavy metals reported by $\mathrm{Wu}$ et al., (2011), are due to their prolonged persistent stay in the environment unchanged, their ability to be recycled biochemically in the same form that they were, their ability to accumulate and increase their concentration biologically, their biological toxicity to flora and fauna, their capability to undergo reduction \& oxidation reactions with or without availability of oxygen, their ability to undergo precipitation, solubilisation, to aggregate or flocculate in solutions, the ability of their ligands to undergo chelation and finally their ability to put all the above together and be toxic in nature (Ademoroti, 1996). Some are carcinogenous, damage digestive systems (Fawell et al., 2003), cause hallucination to even forgetfulness (Du et al., 2011), lung cancer or nasal tumours and even affect DNA (Fawell et al., 2007). Pb affects haemoglobin in blood and can even transfer into foetus through umbilical cord and causes adverse mental situations in small amounts (Cotruvo et al., 2011). Water treatment chemicals are also a huge source and contributors to reaction by-products that lead to health risk. Depending on $\mathrm{pH}$ and temperature, sedimentation/flocculation processes produces $\mathrm{Al}^{3+}$, $\mathrm{Fe}^{2+, 3+}$ by-products of organic and inorganic anions are formed (Sielechi et al., 2010). Disinfection process using chlorine or Sodium hypochlorite [HTH] powder effectively produces hypochlorous acid that enables the disinfection but with other significant organic byproducts like trihalomethanes [THM], haloacetic acids, haloacetonitriles, chloral hydrate, etc, while ozone disinfectant produces by-products like bromoform, monobromoac, etc are amongst the contaminants effectively in the spent SFM dumpsites. The surface mobility, biochemical redox reactions and underground bioaccumulation of heavy metal contaminants in spent or used sand filter media [SFM] and their related impact in the ecosystem is of considerable concern to chemists and other environmentalists around the world (Leizou et al., 2015). The phenomenon of sorption and migration are the basic principles of the study of physical speciation or distribution in the sand filter media dumpsites (Templeton et al., 2000). The study of speciation is therefore very important in the field of chemical, biological, environmental and geochemical researches. Specifically, speciation is necessary in the determination of the concentration of an element in different spots in a sampled area and gives a defined conclusion about the mobility and bioavailability of species (Leizou et al., 2015). It helps to determine toxicity by measuring the concentration of some each 
species of that element as the total concentration of the heavy metal alone does not give the complete idea of the potential risk of that element in the area studied (Cui and Du, 2011, Ayadin and Kucuksezgin 2012, Beltran, et al. 2010). The Chemical Sequential Extraction CSE procedure, was first developed by Tessier et al., 1979 and modified in other form by several researchers (Oake et al., 1984, Campbell et al., 1995). The 5-stage sequential extraction procedure established by Tessier and modified by Carliel showed extraction of stages 1 - 5; Exchangeable metal fraction, Carbonate metal fraction, $\mathrm{Fe} / \mathrm{Mn}$ oxide fractions. Organic matter/Sulphide fraction and the Residual fraction. This paper focuses on the investigation of the distribution and speciation of $\mathrm{Cr}, \mathrm{Fe}, \mathrm{Mn}, \mathrm{Ni}$ and $\mathrm{Pb}$ in sand-filter-media [SFM] waste dumpsites in Yenagoa, Nigeria and the biochemical availability of the metals for intake by living organisms.

\section{MATERIALS AND METHODS}

The study city, Yenagoa is the capital city of Bayelsa State, Nigeria and lies between latitude $4^{\circ} 50^{\prime}$ to $5^{\circ} 00^{\prime}$ North and longitude $6^{\circ} 11^{\prime}$ to $6^{\circ} 25^{\prime}$ East (AmosTantua et al., 2001, Agbalagba et al., 2014). The water facility and SFM dumpsite is located at Geographic Positioning System [GPS] 4.934245, 6.266297 interpreted to read $4^{\circ} 56^{\prime} 03.3^{\prime}$ ' $\mathrm{N} 6^{\circ} 15^{\prime} 58.7^{\prime}$ ' E.

Sampling: Three distinct soil samples were obtained. Sample Aтм was $2 \mathrm{~kg}$ deposit of Sand-Filter-Media [SFM] collected on the surface of the dumpsite between $0-10 \mathrm{~cm}$ in five (5) different points in the sample location using a soil auger. Half of these were put separately in a black plastic bag, labelled sample $\mathrm{A}_{\mathrm{TM}}$ 1, 2-5, stored in a cool place for digestion and analysis of total metal of $\mathrm{Pb}, \mathrm{Fe}, \mathrm{Ni}, \mathrm{Cr}$ and $\mathrm{Mn}$. The other half of the five portions were mixed together to get a representative sample of the entire top surface of the SFM dumpsite and put into a plastic bag, labelled as Sample $\mathrm{A}_{\mathrm{TM}}$ and stored in a cool place. Sample B was collected at a depth of $100 \mathrm{~cm}$ in a $100 \mathrm{~cm} \times 100 \mathrm{~cm}$ x $200 \mathrm{~cm}$ vertical hole dug with a shovel down the centre of SFM dumpsite. Four separate samples were collected after the $100 \mathrm{~cm}$ marked depth at the four corners of the $100 \mathrm{~cm} \times 100 \mathrm{~cm} \times 200 \mathrm{~cm}$ hand-dug hole. The collected four samples from the four-corners were mixed together to get a representative sample at $100 \mathrm{~cm}$ depth and $1 \mathrm{~kg}$ of the representatively mixed sample was put into a plastic bag and stored in a cool place and labelled Sample B. Sample C was collected at the surface of the top soil of an unoccupied land space at a distance of about $100 \mathrm{~m}$ away from the SFM dumpsite, as a control sample. About excess of $1 \mathrm{~kg}$ of each sample was collected, stored in a cool place

Sequential Extraction: Chemical speciation using 5stage extraction procedures and the extraction reagents were prepared using standard procedure and analytical grade reagents as specified in Tessier et al., (1980) and modified by Oake et al., (1984) and summarised by
Carliel and Wheatley (1997) based on the five pillars of extraction being the exchangeable metals, adsorbed metals, organic-bound metals, metal carbonates and Sulphides. The fractions were obtained using $1 \mathrm{~g}$ of each portion of samples A, B, and C. $1 \mathrm{~g}$ of the samples were sieved, weighed and put into $100 \mathrm{ml}$ sampling bottles. To each sample bottle, $16 \mathrm{ml}$ of $\mathrm{MgCl}_{2}$ at $\mathrm{pH} 7$ was added and allowed for 1 hour at room temperature. The mixture was shaken carefully throughout the period and the extract carefully decanted into $15 \mathrm{ml}$ analytical vessel and labelled A1, B1 and C1 representing the fraction of Exchangeable Metals. The extractant removed the metals bound by exchange sites in the SFM such that when the sample is saturated with $\mathrm{Mg}^{2+}$, exchangeable metals would be displaced from the exchangeable sites. To the residue after decanting, $16 \mathrm{ml}$ of $1 \mathrm{M}$ Sodium acetate was added and then acetic acid buffer was added to bring the $\mathrm{pH}$ to 5 . This mixture was continuously shaken at room temperature for a period of 5 hours and then extracted to remove the Metal Carbonate fraction. The extract was decanted into $15 \mathrm{ml}$ sample bottles and labelled A2, B2 and $\mathrm{C} 2$. This fraction represents mainly the microbial uptake of metals as it evolves due to microbiological activities in the sediments/sludge due to available $\mathrm{CO}_{2}$. For the $\mathrm{Fe} / \mathrm{Mn}$ oxide fraction, $20 \mathrm{ml}$ of $0.4 \mathrm{M}$ $\mathrm{NH}_{2} \mathrm{OH} . \mathrm{HCl}$ hydroxylamine Hydrochloride in $20 \%$ $\mathrm{v} / \mathrm{v}$ acetic acid HOAc was added to the residues of A, $\mathrm{B}$ and $\mathrm{C}$ after decanting fraction 2 . The mixture was heated to about $96^{\circ} \mathrm{C}$ in a water bath and kept steady for 6 hours. The extract was decanted into $15 \mathrm{ml}$ sample bottles, labelled A3, B3 and C3. To the residue from fraction $3,3 \mathrm{ml}$ of $0.02 \mathrm{M} \mathrm{HNO} 3$ was added to $5 \mathrm{ml}$ of $30 \% \mathrm{v} / \mathrm{v} \mathrm{H}_{2} \mathrm{O}_{2}$ and adjusted to $\mathrm{pH} 2$. The mixture was added to the residue from fraction 3 and heated in a water bath to $85^{\circ} \mathrm{C}$ for a period of 2 hours with occasional shaking and then allowed to cool. Thereafter, another $3 \mathrm{ml}$ of $30 \% \quad \mathrm{H}_{2} \mathrm{O}_{2}$ which was adjusted to $\mathrm{pH} 2$ with $\mathrm{HNO}_{3}$ was added to the mixture. This was then heated again to $85^{\circ} \mathrm{C}$ for another 3 hours with occasional shaking and allowed to cool. Lastly, $5 \mathrm{ml}$ of a mixture of $3.2 \mathrm{M} \mathrm{NaOAc}$ mixed with $20 \%$ $\mathrm{HNO}_{3}$ which was diluted to $20 \mathrm{ml}$ volume with deionised water, was added. The mixture was decanted and the extract was put into $15 \mathrm{ml}$ sample bottle, labelled as A4, B4, and C4 representing the Organic/Sulphide fraction. Lastly, the residual or inert residual from fraction 4 was transferred to a crucible and dried in an oven at $105^{\circ} \mathrm{C}$. Thereafter, a mixture of $5 \mathrm{ml}$ conc. $\mathrm{HNO}_{3} 70 \% \mathrm{w} / \mathrm{w}$ with $10 \mathrm{ml} \mathrm{HF} \mathrm{w/w} 40 \%$ with $10 \mathrm{ml}$ of $\mathrm{HClO}_{4} 60 \% \mathrm{w} / \mathrm{w}$, was added in a fume chamber. The mixture was allowed to cool and $10 \mathrm{ml}$ of distilled water was added. The mixture was filtered into $100 \mathrm{ml}$ volumetric flask and de-ionised water was added to make it to $100 \mathrm{ml}$ mark. A portion of $15 \mathrm{ml}$ was again transferred to a $15 \mathrm{ml}$ sample bottle and labelled A5, B5 and C5 representing the residual metal fractions. Analysis of the heavy metals concentration for lead $(\mathrm{Pb})$, Iron $(\mathrm{Fe})$, Nickel $(\mathrm{Ni})$, Chromium $(\mathrm{Cr})$ and Manganese (Mn) was done using a Buck Scientific 
210 VGP Flame Atomic Absorption Spectrophotometer FAAS following prescribed procedures.

Statistical Evaluations: Evaluation of relationship of results using calculations of the Pearson's Correlation Coefficient is given as thus;

Correlation Coefficient, $r=\frac{\sum d_{A} d_{B}}{\sqrt{\sum d_{A}^{2} \sum d_{B}^{2}}}$

Where, $d_{A}$ and $d_{B}$ are concentration results at the sample points A and B. Calculated Correlation Coefficient, $r$ is 0.9959611 . Correlation Coefficient, $r$, was read in the standard table with $n=3$ [being 2 less than the 5 heavy metals as variables considered] are 0.991 at probability of $0.001,0.959$ at probability of 0.01 , and 0.878 at probability of 0.05 . For correlation to be significant, the calculated $r$ value should exceed the tabulated value $r$ value. The calculated Correlation Coefficient, $r$, is higher than the tabulated values at all probabilities. This implies that the correlation in the results at the top and $100 \mathrm{~cm}$ depth below the SFM waste dumpsites show significant correlation (Horsfall et al., 1994; Horsfall 2014).

\section{RESULTS AND DISCUSSION}

The cumulative speciation results obtained from all the analysis done with 210 VGP FAAS for the five selected heavy metals is showed in table 1 .

\begin{tabular}{llllll}
\multicolumn{5}{c}{ Table 1. Heavy } & Metals Levels in Sand Filter Media $[\mathrm{SFM}]$ Waste Dumpsite in Yenagoa, Nigeria \\
\hline Sample ID & $\begin{array}{l}\text { Lead, } \\
\mathrm{Pb}[\mathrm{mg} / \mathrm{kg}]\end{array}$ & $\begin{array}{l}\text { Iron, } \\
\text { Fe }[\mathrm{mg} / \mathrm{kg}]\end{array}$ & $\begin{array}{l}\text { Nickel, Ni } \\
{[\mathrm{mg} / \mathrm{kg}]}\end{array}$ & $\begin{array}{l}\text { Chromium, } \\
\mathrm{Cr}[\mathrm{mg} / \mathrm{kg}]\end{array}$ & $\begin{array}{l}\text { Manganese, } \\
\text { Mn [mg/kg] }\end{array}$ \\
\hline Sample A TM & 0 & 12.5 & 0.2 & 1.91 & 1.25 \\
Sample B TM & 0 & 12.3 & 0.29 & 2.14 & 0.28 \\
Sample C TM & 0 & 12.1 & 0.28 & 2.29 & 0.85 \\
Sample A1 & 3.18 & 11.8 & 2.59 & 7.67 & 1.6 \\
Sample B1 & 2.53 & 3.2 & 2.65 & 7.92 & 1.42 \\
Sample C1 & 3.08 & 1.6 & 2.71 & 8.01 & 1.55 \\
Sample A2 & 0.2 & 10 & 2.36 & 3.56 & 0.63 \\
Sample B2 & 0.12 & 5.9 & 2.4 & 3.71 & 0.86 \\
Sample C2 & 0.06 & 1.3 & 2.44 & 3.9 & 0.89 \\
Sample A3 & 0.01 & 10.9 & 0.65 & 2.61 & 1.28 \\
Sample B3 & 0.02 & 8.8 & 0.22 & 2.35 & 0.43 \\
Sample C3 & 0.06 & 5.9 & 0.28 & 2.22 & 1.06 \\
Sample A4 & 0.06 & 10.7 & 0.17 & 2.55 & 0.42 \\
sample B4 & 0.03 & 9.8 & 0.21 & 2.64 & 0.32 \\
sample C4 & 0.11 & 5.9 & 0.11 & 2.85 & 0.41 \\
Sample A5 & 0.06 & 10.9 & 0.16 & 0.18 & 0.36 \\
Sample B5 & 0.07 & 10.9 & 0.26 & 0.38 & 0.33 \\
Sample C5 & 0.8 & 10.6 & 0.06 & 0.59 & 0.61 \\
\hline
\end{tabular}

Speciation of Lead: The speciation pattern for $\mathrm{Pb}$ at the top of SFM dumpsite as shown in figure 1 revealed that $\mathrm{Pb}$ occurred most in the exchangeable fraction with $90.06 \%$, followed by Carbonate fraction with $5.70 \%$, the Organic and Residual fractions has $1.71 \%$ respectively while the lowest was $\mathrm{Fe} / \mathrm{Mn}$ fraction with $0.28 \%$. This result indicates that $\mathrm{Pb}$ which accumulates most in the exchangeable and carbonate fractions was readily biochemically available for intake or exchange on the surface of the SFM dumpsite and so it is a potential risk to biota around the vicinity of the dumpsite (Leizou et al., 2015). The speciation pattern of $\mathrm{Pb}$ at $100 \mathrm{~cm}$ depth below the surface of the dumpsite is presented in figure 2 . The results showed that $\mathrm{Pb}$ in the exchangeable fraction increased to $91.34 \%$ from $90 \%$. This higher value indicates that there is slight migration of some heavy metals down the dumpsite due to leaching. The high percentage of $\mathrm{Pb} 100 \mathrm{~cm}$ below the surface of the dump also means that $\mathrm{Pb}$ is available for biological uptake at this depth. Thus plant roots and soil animals are likely to accumulate $\mathrm{Pb}$ in their system more than those on the surface (Cui and Du, 2011). However, the carbonate fraction of $\mathrm{Pb}$ decreased from $5.2 \%$ on the top layer (figure 1) to $4.33 \%$ at $100 \mathrm{~cm}$ in Fig 3. This difference in concentration could be attributed to lower $\mathrm{pH}$ values at the $100 \mathrm{~cm}$ depth of the SFM dumpsite and the carbonates or metals co-precipitated with carbonates go into solution as the carbonate equilibrium is altered due to the pH drop (Namiesnik and Rabajczyk, 2010). The Fe/Mn fraction increased from $0.28 \%$ to $0.72 \%$. The Residual inactive fraction also increased from $1.71 \%$ to $2.53 \%$. It can be deduced that some of the Carbonates and Organic fractions reduced down the formation to cause an increase in the Residual fraction.

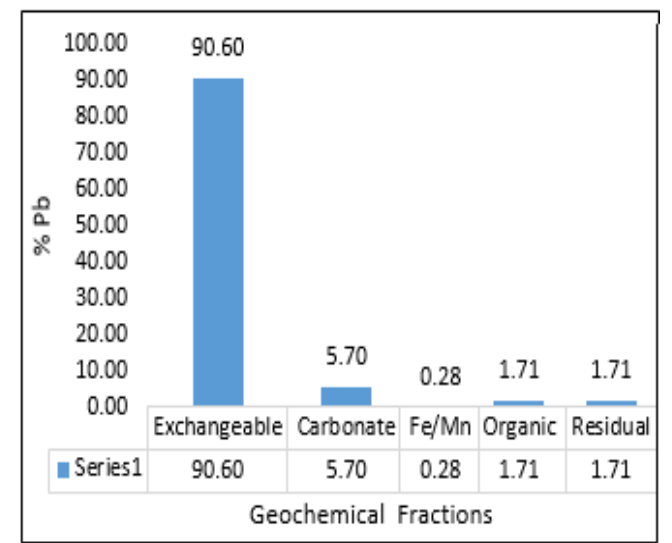

Fig 1. Percent Distribution of $\mathrm{Pb}$ at the surface layer of Sand Filter Media [SFM] Waste Dumpsite 


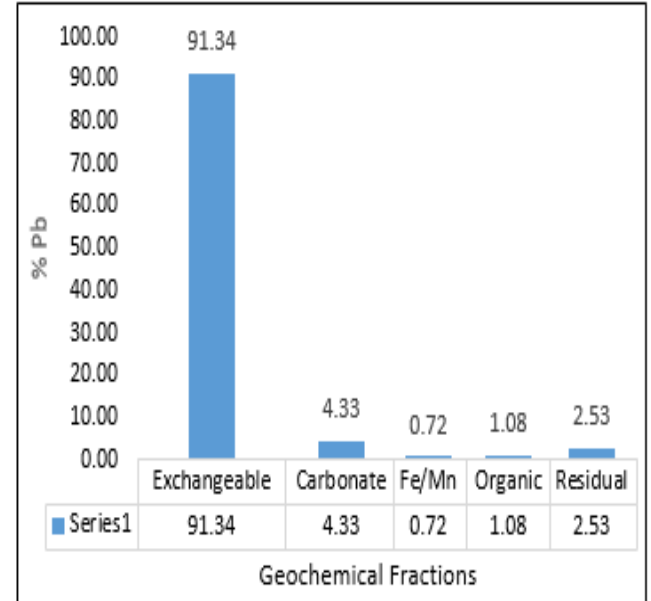

Fig 2. Percent Distribution of $\mathrm{Pb}$ at $100 \mathrm{~cm}$ depth of the Sand Filter Media [SFM] Waste Dumpsite

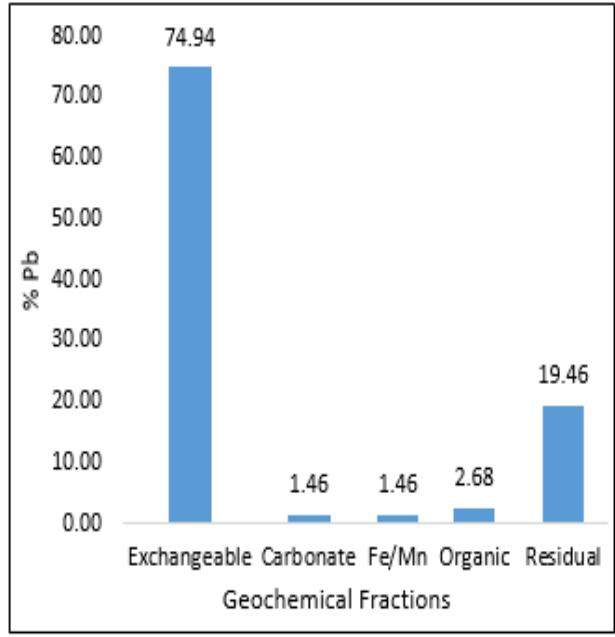

Fig 3. Percent Distribution of $\mathrm{Pb}$ at 100 meters away from the Sand Filter Media [SFM] Waste Dumpsite

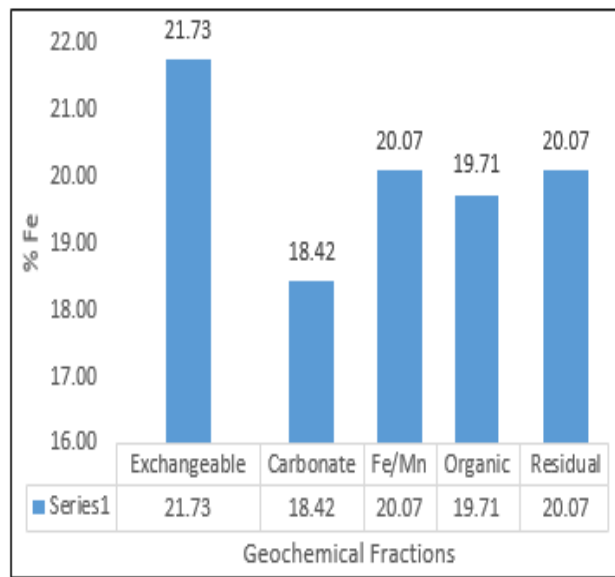

Fig 4. Percent Distribution of Fe at the surface layer of Sand Filter Media [SFM] Waste Dumpsite

The speciation of $\mathrm{Pb}$ in the five (5) fractions away from the dumpsite [samples C] is given in figure 3 . Exchangeable $\mathrm{Pb}$ fraction was $74 \%$ which is lower than those from the dumpsites at the top and below. The Carbonate fraction also decreased to $1.46 \%$ thereby adding to the decrease in the bio-available $\mathrm{Pb}$ amount in the area. In addition, the Residual amount of $\mathrm{Pb}$ increased to $19.46 \%$. This suggests that away from the dumpsite, there was decrease in bio-available $\mathrm{Pb}$ caused by the decrease in exchangeable and Carbonate $\mathrm{Pb}$ and increase in the residual $\mathrm{Pb}$ fraction. Thus, $\mathrm{Pb}$ is less available for plant and animal uptake in the area $100 \mathrm{~m}$ away from the dump site.

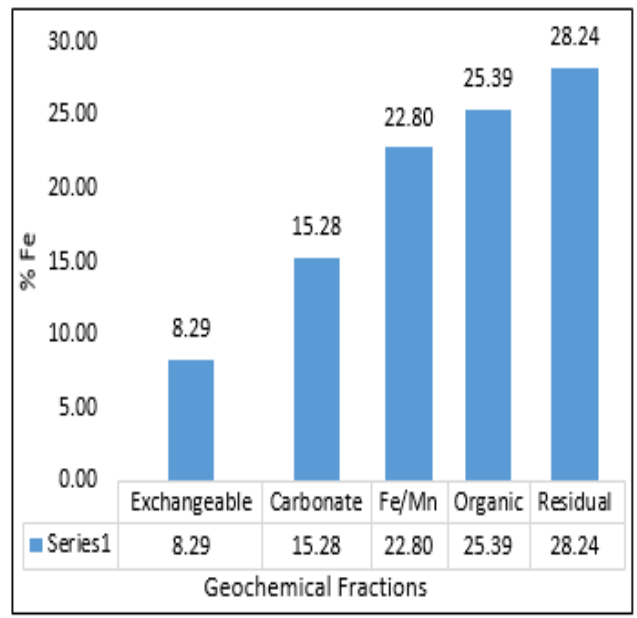

Fig 5. Percent Distribution of Fe at $100 \mathrm{~cm}$ depth of the Sand Filter Media [SFM] Waste Dumpsite

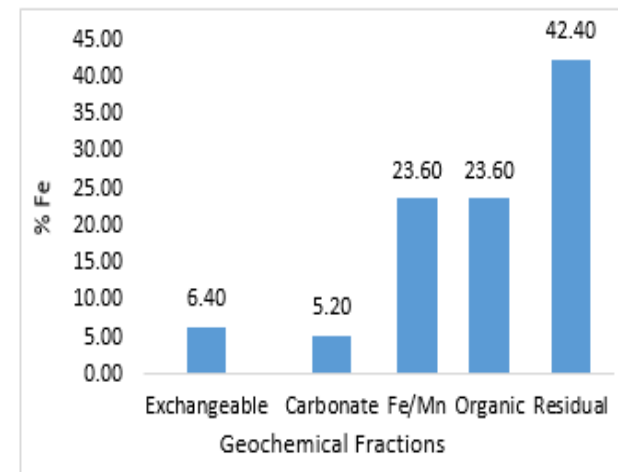

Fig 6. Percent Distribution of Fe at 100 meters away from the Sand Filter Media [SFM] Waste Dumpsite

Iron Speciation: The total amount of Fe at the top of the SFM [Sample A] was $10.0 \mathrm{mg} / \mathrm{kg}$ as against that of $\mathrm{Pb}$ which was $0.2 \mathrm{mg} / \mathrm{kg}$. The results for Fe fractions at the top of the dumpsite as given in figure 4 was quite close from maximum of 18.42 to minimum of $21.73 \%$ unlike $\mathrm{Pb}$. The results showed that the exchangeable fraction of $\mathrm{Fe}$ in the sample was $21.73 \%$, the $\mathrm{Fe} / \mathrm{Mn}$ and Residual fractions was $20.07 \%$ each, and the Organic fraction was $19.71 \%$ while the carbonate fraction of $\mathrm{Fe}$ was $18.42 \%$. The results show a seemingly even distribution when compared with the speciation of $\mathrm{Pb}$ with over $90 \%$ in the exchangeable fraction. This means that Fe was more concentrated $(10 \mathrm{mg} / \mathrm{kg} \mathrm{Fe}$ against $0.2 \mathrm{mg} / \mathrm{kg} \mathrm{Pb})$, thus it is also 
biologically available like $\mathrm{Pb}$. There was increase in other less biologically available fractions, like the Carbonate fraction increased to 18.42 against that of $\mathrm{Pb}$ which was $5.70 \%$, Fe/Mn increased to $20.07 \%$ against the of $\mathrm{Pb}$ which was at 0.28 , Organic fraction increased from $1.71 \%$ in $\mathrm{Pb}$ to $19.71 \%$ in $\mathrm{Fe}$ while Residual fraction increased from $1.71 \%$ in $\mathrm{Pb}$ to $20.02 \%$ in Fe all from Samples collected at the top of the dumpsite (Kim, et al. 2010). The speciation of Fe at $100 \mathrm{~cm}$ below the surface of the dumpsite [sample $\mathrm{B}$ ] gave a decrease in the $\mathrm{Fe}$ distribution in the exchangeable Fraction and the Carbonate fraction being $8.29 \%$ and $15.28 \%$ respectively as against the fractions at the top which were 21.73 and 18.42 respectively. This means that there was decrease in the percentage of $\mathrm{Fe}$ that was biologically available at the $100 \mathrm{~cm}$ depth [figure 5]. This decreased bioavailability was confirmed by the increased percentage of Residual, Organic and $\mathrm{Fe} / \mathrm{Mn}$ fraction which were $28.24 \%, 25.39 \%$ and $22.80 \%$ as against $20.03 \%, 19$, $71 \%$ and $20.07 \%$ respectively at the top of the dumpsite.

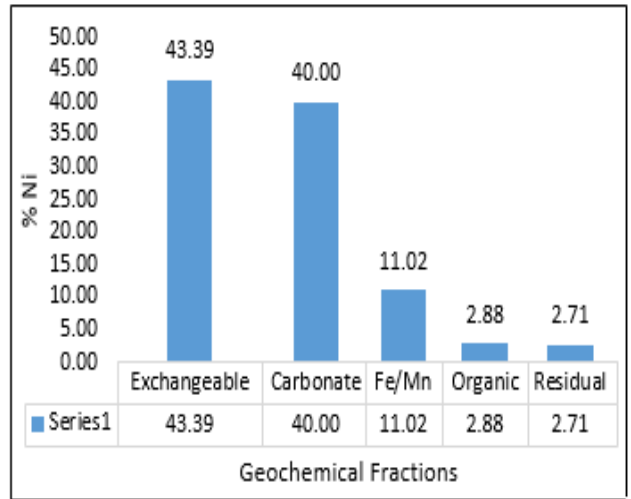

Fig 7. Percent Distribution of $\mathrm{Ni}$ at the surface layer of Sand Filter Media [SFM] Waste Dumpsite

Speciation results of Fe distribution from Sample C showed that the percentage concentration of Fe in the exchangeable and Carbonate fractions continued to decrease to $6.40 \%$ and $5.20 \%$ at $100 \mathrm{~m}$ away from the dumpsite as compared to $8.29 \%$ and $15.28 \%$ at the bottom and $21.73 \%$ and $18.42 \%$ at the top of the dumpsite. Percentages of the inert or less biologically available fraction of the residual, Organic and $\mathrm{Fe} / \mathrm{Mn}$ fraction recorded increase to $42.40 \%, 29.60 \%$ and $23.60 \%$ respectively. The dumpsite has more active HMs than the control sample (Ashraf et al., 2012).

Nickel Speciation: The speciation of $\mathrm{Ni}$ at the top of the dumpsite [sample A] gave the exchangeable and carbonate fractions as the highest being 43.395 and $40.00 \%$ respectively. The trend of the percentage distribution of the other fraction were $31.02 \%$ for $\mathrm{Fe} / \mathrm{Mn}, 2.88 \%$ for Organic and $2.71 \%$ for residual fractions respectively. The results showed that at the surface of the dumpsite, Ni exists more in the fractions that are most available to biological species.
Speciation of Ni at $100 \mathrm{~cm}$ depth of SFM [sample B] showed that the fraction of Exchangeable and Carbonate bound Ni increased to $46.17 \%$ and $41.81 \%$ respectively. While there was reduction in the fractions of $\mathrm{Fe} / \mathrm{Mn}$ to $3.83 \%$ from $11.02 \%$ at the top. Organic and Residual fractions increased to $3.66 \%$ and $4.53 \%$ respectively from $2.88 \%$ and $2.71 \%$ respectively at the top of the dumpsite.

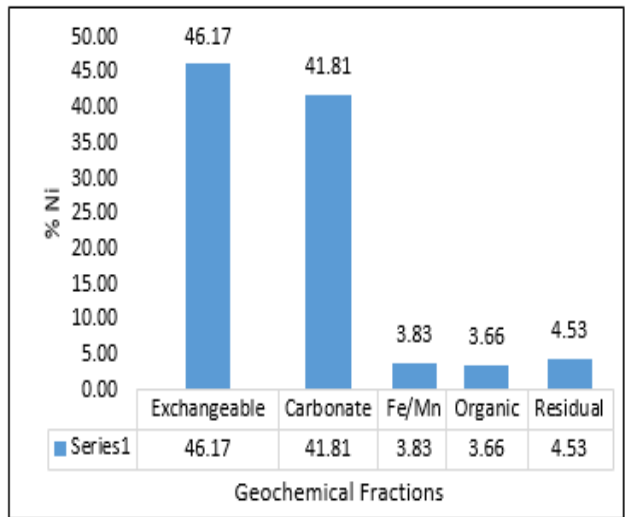

Fig 8. Percent Distribution of $\mathrm{Pb}$ at $100 \mathrm{~cm}$ depth of the Sand Filter Media [SFM] Waste Dumpsite

The speciation of $\mathrm{Ni}$ in the sample collected $100 \mathrm{~m}$ away [sample C] showed that the Exchangeable and Carbonate fractions were highest with $48.39 \%$ and $43.57 \%$ while the other fractions of $\mathrm{Fe} / \mathrm{Mn}$, Organic and Residual were $5.00 \%, 1.96 \%$ and $1.07 \%$ respectively. The trend for speciation of $\mathrm{Ni}$ at $100 \mathrm{~m}$ distance away from the dumpsite surprisingly showed high availability of $\mathrm{Ni}$ for biological intake like the samples in the dumpsite.

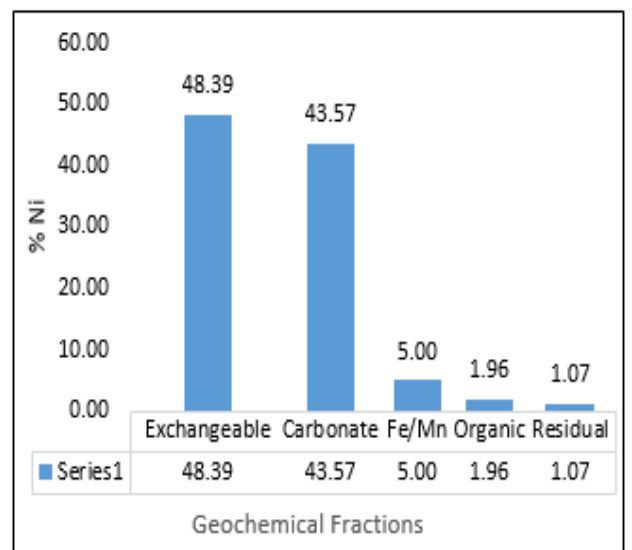

Fig 9. Percent Distribution of Ni at 100 meters away from the Sand Filter Media [SFM] Waste Dumpsite

Chromium Speciation: The speciation of $\mathrm{Cr}$ at the top of the dumpsite [Sample a] had $46.29 \%$ in the Exchangeable fraction, $21.48 \%$ in the Carbonate fraction, $15.75 \%$ in thee $\mathrm{Fe} / \mathrm{Mn}$ fraction, $15.39 \%$ in the Organic fraction and $1.90 \%$ in the residual fraction. This showed that $\mathrm{Cr}$ was highest in the exchangeable fraction and lowest in the inactive residual fraction. 
The high percentage of $\mathrm{Cr}$ in the exchangeable fraction indicates that there is availability of $\mathrm{Cr}$ for biota in that environment.

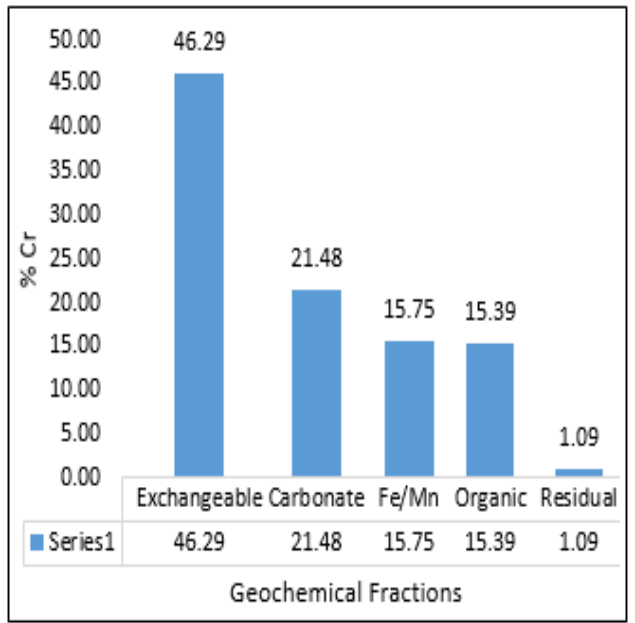

Fig 10. Percent Distribution of $\mathrm{Cr}$ at the surface layer of Sand Filter Media [SFM] Waste Dumpsite

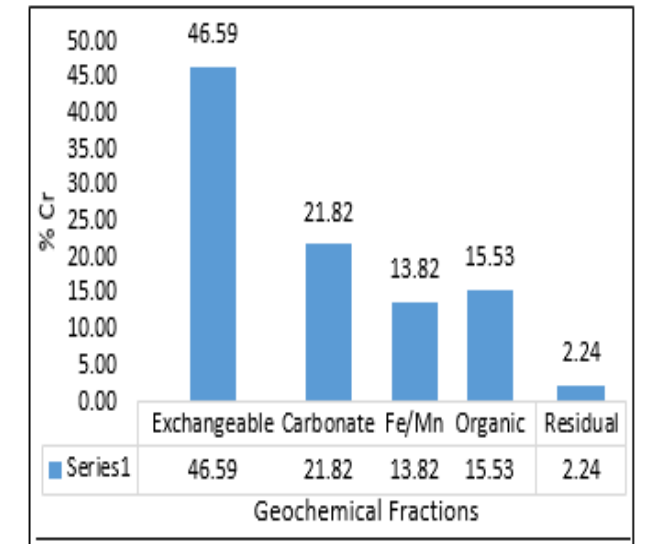

Fig 11. Percent Distribution of $\mathrm{Cr}$ at $100 \mathrm{~cm}$ depth of the Sand Filter Media [SFM] Waste Dumpsite

Consequently, the availability of $\mathrm{Cr}$ in the sand filter media was Exch $>>$ Carb. $>$ Fe/Mn $>$ Org. $>$ Res. The speciation of $\mathrm{Cr}$ at $100 \mathrm{~cm}$ below the surface of the dumpsite [Sample B] followed the same trend for the top surface. Results showed that the Exchangeable fraction was highest with $46.59 \%$, just a little higher than the one from the top of the dumpsite. This was followed by Carbonate fraction that was $21.82 \%$, which was also only slightly higher than $21.48 \%$ from the sampled top. Other fractions also trended the same with the lowest being the residual fraction which is $2.24 \%$ and slightly lower than $1.09 \%$ from the sampled top. The trend revealed mobility of HMs down the dumpsite. This implies that at the depth of $100 \mathrm{~cm}$ below the $\mathrm{Cr}$ in the dumpsite was biologically available and will be bio- accumulated, if taken. The speciation pattern of $\mathrm{Cr} 100 \mathrm{~m}$ away from SFM [sample C] relatively showed the same trend wherein the Exchangeable fraction as the highest being 49.99\% while the Residual fraction was the lowest $3.36 \%$.
There is bioavailability of the $\mathrm{Cr}$ in the sample for uptake by biota possible causing bioaccumulation.

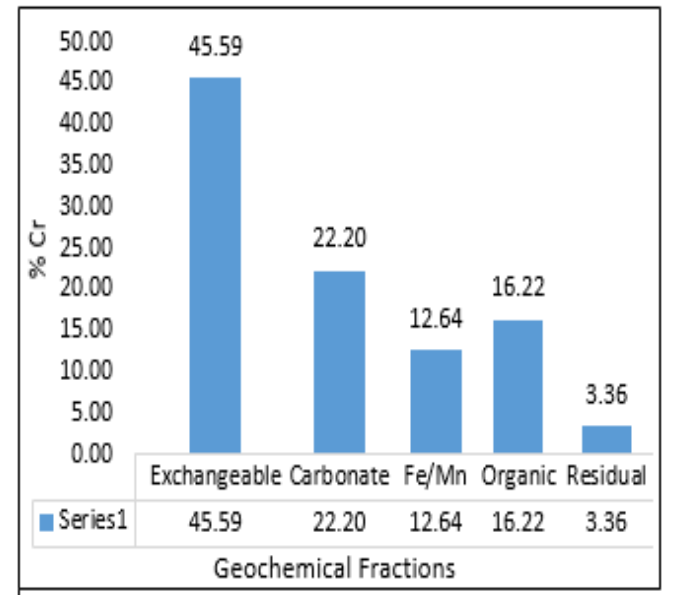

Fig 12. Percent Distribution of $\mathrm{Cr}$ at 100 meters away from the Sand Filter Media [SFM] Waste Dumpsite

Manganese Speciation: The speciation of $\mathrm{Mn}$ in the sample collected from the top of the dumpsite had exchangeable fraction of $37.30 \%$, carbonate fraction of $14.69 \%$, much higher $\mathrm{Fe} / \mathrm{Mn}$ fraction of $29.84 \%$, which is the highest of the $\mathrm{Fe} / \mathrm{Mn}$ in all the samples collected. Organic and residual fractions were 9.79\% and $8.39 \%$ respectively. Biological available exchangeable fraction of Mn was highest in percentage about a third of the others. This means that $\mathrm{Mn}$ is readily available for biota intake and bioaccumulation processes.

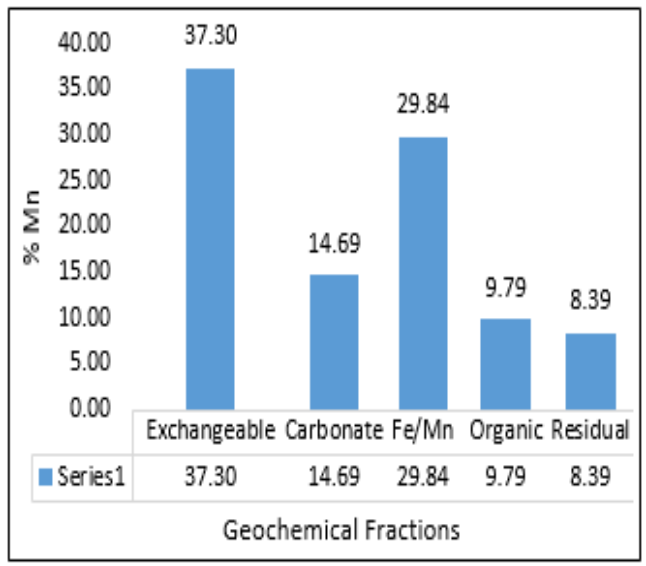

Fig 13. Percent Distribution of Mn at the surface layer of Sand Filter Media [SFM] Waste Dumpsite

$100 \mathrm{~cm}$ below the SFM dumpsite [sample B], speciation results for $\mathrm{Mn}$ revealed that the exchangeable fraction increased to $42.26 \%$ from $37.30 \%$, Carbonate fraction also increased to $25.60 \%$ from $14.69 \%$ while $\mathrm{Fe} / \mathrm{Mn}$ fraction reduced to $12.80 \%$ from 29.84\% This showed mobility of $\mathrm{HMs}$ downward. Other fraction like Organic and Residual fractions still remained in the vicinity of $9.52 \%$ and $9.82 \%$ respectively. The trend again showed that $\mathrm{Mn}$ 
is biologically available and infact its availability slightly increased down the SFM dumpsite.

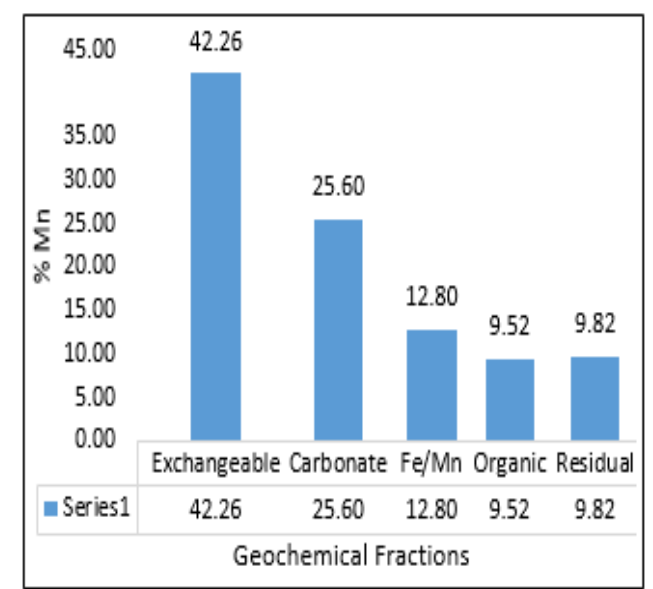

Fig 14. Percent Distribution of Mn at $100 \mathrm{~cm}$ depth of the Sand Filter Media [SFM] Waste Dumpsite

The distribution of $\mathrm{Cr}$ at $100 \mathrm{~m}$ away from the SFM, gave exchangeable fractions as highest with $34.29 \%$, $\mathrm{Fe} / \mathrm{Mn}$ fraction as $23.45 \%$, Carbonate fraction as $19.69 \%$, Residual as $13.50 \%$ and Organic fraction as lowest with $9.07 \%$. Results still revealed the exchangeable fraction as highest even at the control sample.

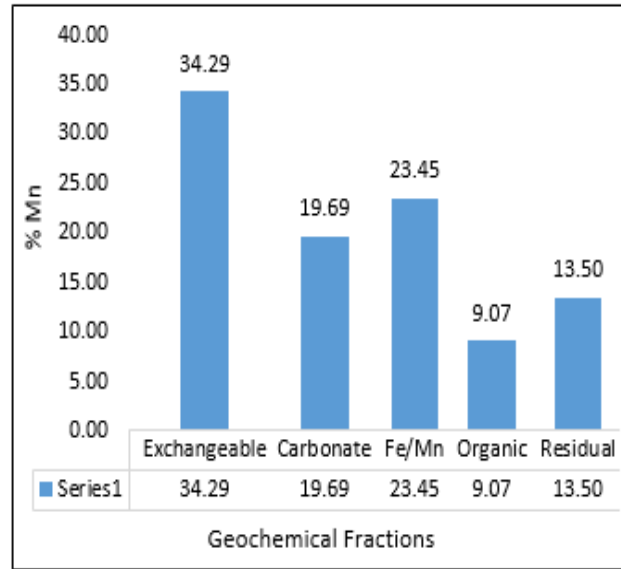

Fig 15. Percent Distribution of $\mathrm{Pb}$ at 100 meters away from the Sand Filter Media [SFM] Waste Dumpsite

The investigation of distribution and speciation of five Heavy Metals [HMs] in spent Sand Filter Media [SFM] dumpsite investigated with a view to ascertain the total heavy metals in the SFM and the chemical speciation of the heavy metals concluded that Fe had highest concentration while $\mathrm{Pb}$ had the lowest concentration in the order;

$\mathrm{Fe}>>>\mathrm{Cr}>\mathrm{Mn}>\mathrm{Ni}>\mathrm{Pb}$

The investigation of the chemical speciation of the metals concluded that the trend of geochemical fractions follows the order;
$\mathrm{Pb}$ Speciation: Exchangeable $>>>$ Carbonate $>$ Organic $=$ Residual $>$ Fe $/ \mathrm{Mn}$

Fe Speciation: Residual $>$ Organic $>\mathrm{Fe} / \mathrm{Mn}>$ Carbonate $=$ Exchangeable

Ni Speciation: Exchangeable $>$ Carbonate $>>$ $\mathrm{Fe} / \mathrm{Mn}>$ Residual $>$ Organic

Cr Speciation: Exchangeable $>>$ Carbonate $>$ Organic $>\mathrm{Fe} / \mathrm{Mn}>$ Residual

Mn Speciation: Exchageable $>\mathrm{Fe} / \mathrm{Mn}>$ Carbonate $>$ Residual $>$ Organic

It is concluded that the concentration of the five heavy metals studied had $\mathrm{Fe}$ as having the highest concentration but this was spread evenly amongst the geochemical fractions while the other four metals $(\mathrm{Pb}$, $\mathrm{Cr}$, Ni and $\mathrm{Mn}$ ) had more of their geochemical fractions in the exchangeable, carbonate, $\mathrm{Fe} / \mathrm{Mn}$ and Organic fractions which means that these HMs are of high mobility and thus biochemically available for interaction and intake by biota. Therefore, these metals portend contamination of the ecosystem in the sand filter media [SFM] dumpsite possibly due to bioaccumulation.

Acknowledgement: Ikoko is grateful to the Bayelsa State Ministry of Water Resources for granting me permission to complete a $\mathrm{PhD}$ programme

\section{REFERENCES}

Ademeroti, CMA, 1996. Environmental Chemistry and Toxicology. March Prints and Consultancy.

Agbalagba, EO; Agbalagba, OH; Onunugbo, CP; Alao, AA (2011). Investigation into the Physicochemical Properties and Hydrochemical Processes of Groundwater from Commercial Boreholes In Yenagoa, Bayelsa State, Nigeria. Afri. J. Env. Sc. \& Tech. 5 (7): 473-481.

Amos-Tantua, BMW; Onigbinde, AO; Ere, D (2014). Assessment of some Heavy Metals and Physicochemical Properties in Surface Soils of Municipal Open Waste Dumpsite in Yenagoa, Nigeria. Afri. J. Env. Sc. \& Tech. 8 (1): 41-47.

Ashraf, MA; Maah, MJ; Yusoff, I (2012). Chemical Speciation and Potential Mobility of Heavy Metals in the Soil of Former Tin Mining Catchment. The Science World Journal 1-9.

Aydin, S; Kucuksezgin, F (2012). Distribution and chemical speciation of heavy metals in the surficial sediments of the Bakırc, ay and Gediz Rivers, Eastern Aegean. Env. Earth Sc. J. (Spriner Verlaf 2011) 65: 789-803.

Beltran, R; De la Rosa, JD; Santos, JC; Beltran, M; Gomez-Ariza, JL (2010). Heavy metal mobility assessment in sediments from the Odiel River (Iberian Pyritic Belt) using sequential extraction. 
Env. Earth Sc. J. (Springer Verlag) 61: 14931502.

Campbell, PGC (1995). Interactions between trace metals and aqua. Organisms: a critique of the freeion activity model. In: Tessier, A.; Turner, DR. Eds, Metal Speciation \& Bioav. in Aqua Sys. Wiley, Chichester, pp. 45

Cotruvo, JJ; Fawell, JK; Giddings, M; Jackson, P; Magara, HY; Festo-Ngowi, AV; Ohanian, E (2011). Lead in Drinking Water: WHO Guidelines for Drinking Water. In Background document for the development of WHO Guidelines for Drinking Water Quality, 1-15.

Cui, Y; Du, X (2011) Soil heavy-metal speciation and wheat phytotoxicity in the vicinity of an abandoned lead-zinc mine in Shangyu City, eastern China. Env. Earth Sc. J. (Springer Verlag) 62: 257-264.

Du, J; Contruvo, JJ; Giddings, M; Jackson, P; Magara, Y Ohanian, E (2011). Mn in Drinking Water: Background doc. for development of WHO Guidelines for Drinking Water Quality. WHO Report1, 1-15.

Dube, A; Zhytniewski, R; Kowalkowski, T; Cukrowska, E; Buszewski, B (2001). Adsorption and Migration of Heavy Metals in Soil. Polish J. of Env. Studies 10 (1): 1-10.

Horsfall, M; Spiff, AI; Ogban, FE (1994). Petroleum hydrocarbon pollution: The distribution in Sediment and Water of the New Calabar River, Port Harcourt, Nigeria. J. Sci. Total Environ. 141, $217-221$.

Horsfall, M (2014). Fundamental Principles of Analytical Chemistry. First Ed. Port-Harcourt: Soteria Pub. House.

Kim, Y; Byoung-Ki, K; Kim, K (2010). Distribution and speciation of heavy metals and their sources in Kumho River sediment, Korea. Env. Earth Sc. $J$. (Springer Verlag) 60: 943-952.

Leizou, KE; Horsfall, M; Spiff, AI (2015). Speciation of Some Heavy Metals in Sediments of the Pennington River, Bayelsa State, Nigeria. Amer. Chem. Sc. J. 5 (3): 238-246.
Namiesnik, J; Rabajczyk, A (2010). The Speciation and Physicochemical Forms of Metals in Surface Waters and Sediments. Chemical Speciation and Bioavailability 22 (124).

Nariman, H; Mohammed, K (2011). Speciation of Trace Metals in Certain Groundwater in Egypt. Archives of Applied Science Research 3 (4): 118126.

Oake, RJ; O'Neill, P; Williams, J; Davis, RD (1984) Fate of metals in sewage sludge following sea disposal. Environmental Contamination Int'1 Conf., London. (37495). Edinburgh Lothain CEP Consult. Ltd. Co, 555-560

Okoro, HK; Fatoki, OS; Adekola, FA; Ximba, BK; Snyman, RG (2012). A Review of Sequential Extraction Procedures for Heavy Metals Speciation in Soil and Sediments. Open Acc. Sc. Reports 1 (3): 1-9.

Sielechi, JM; Kayem, GJ; Sandu, I (2010). Effect of Water Treatment Residuals (Al and Fe ions) on Human Health and Drinking Water Distribution Systems. Int'l J. Cons. Sc. 1 (3): 175-182.

Templeton, DM; Ariese, F; Cornelis, R; Danielsson, LG; Muntaus, H; Leeuwen, HP; Lobinski, R (2000). Guidelines for Terms related to Chemical Speciation and Fractionation of Elements, Definitions, Structural Aspects and Methodological Approaches. IUPAC 72 (8): 1453-1470.

Tessier, A; Campbell, PGC; Blsson, M (1979) Sequential extraction procedure for the speciation of particulate trace metals. J. Analytical Chemistry, 52 (1): 45-53

World Health Organisation (2011). Guidelines for Drinking Water Quality 4th ed. Geneva: WHO Library Cataloguing-in-Publication Data.

Wu, Z; He, M; Lin, C. Fan, Y. (2011). Distribution and speciation of four heavy metals $(\mathrm{Cd}, \mathrm{Cr}, \mathrm{Mn}$ and $\mathrm{Ni}$ in the surficial sediments from estuary in daliao river and yingkou bay. Env. Sc. J. 63: 163175 